\title{
KDEL Motif
}

National Cancer Institute

\section{Source}

National Cancer Institute. KDEL Motif. NCI Thesaurus. Code C14084.

A motif found at the $\mathrm{C}$ termini of several luminal proteins of the ER that serves to mediate the retention of resident proteins of the ER lumen through retrieval from post-

ER compartments ER via a transport mechanism involving vesicular and tubular elements. 